UDC 811.111'276.6:34]:[821.161.2'25:791]

DOI https://doi.org/10.32841/2409-1154.2019.43.4.26

\author{
Tsymbrylo V.I., \\ Assistant Lecturer at the Department of Translation Studies and Contrastive \\ Linguistics named after Hryhoriy Kochur \\ Ivan Franko National University of Lviv
}

\title{
LEGAL TERMINOLOGY AND THE KEY ISSUES OF ITS REPRODUCTION AS BASED ON THE LEGAL DRAMA SERIES "SUITS"
}

Summary. The article deals with the notion of legal terminology within the framework of Translation Studies and the methods of reproduction and transmission of the legal terms, texts and discourse into the target language.

Law plays a vital role in reinforcing communication between nations and people. Legal translation as a relatively new area of translation gaining more and more popularity on the international scene due to the cultural diversity and globalization of the world has kindled some significant interest in the scholars working in the legal sphere among them V.I. Karaban, S. Sarcevic, A.M. Liashchuk, M.B. Verbieniets, N.A. Ivanova and N.M. Chernovatyi. The differences in the structure and organization of Ukrainian, European and American legal systems in various nations and countries and the lack of academic, theoretical and practical sources that would assist in the process of translation resulted in great demand and need for research in this sphere.

Legal language, as well as other technical languages, fundamentally differs from the language of common use and is often viewed through the prism of legal linguistics, the aim of which is to define the main directions to be studied and researched in legal field, namely the history of the legal linguistics, legal lexicography, forensic linguistics, legal stylistics, legal textology, contrastive legal linguistics and legal terminology. Law in the scope of legal linguistics is expressed by legal terminology, the smallest unit of which is the notion of a legal term.

One of the core problems in legal terminology is solving the problem of reproduction of legal terms. Translating legal terms needs accurate and correct reproduction, thus translators should not only possess general knowledge of legal terminology, but they should also be well aware of requirements, structure and organization of law in that or other culture.

The main factors of translation are formed taking into account the key features of the language culture, type and the mechanism of the social coding of both the source and target languages.

Another challenge that arises in the process of rendering legal terms is the problem of polysemy, namely when the dictionary provides more than one equivalent in the target language and the translator has to refer to the context and extralinguistic information to adequately reproduce the meaning of the given term.

When working on the translation of the terminological expression one must take into account that the language of law needs precise and accurate reproduction as even the smallest deviation may cause an absolute disruption of its meaning. That is the reason why the translator should look for an appropriate equivalent in the target language applying the most suitable method of reproduction.

Key words: legal term, legal linguistics, law, methods of reproduction, lack of correspondence, polysemy.
Legal translation is considered a relatively new area of translation gaining more and more popularity on the international scene due to the cultural diversity and globalization of the world, thus there appears to be a number of problems regarding the proper reproduction of legal terminology. Legal terms are peculiar to one nation but at the same time completely alien to another and therefore pose a challenge in the process of rendering. A proper legal translation requires an adequate, correct, clear and full transfer of content of the source legal term as well as its linguistic form taking into account the structure, style, lexical and grammatical features. Legal translation highlights the importance of accuracy as the translated material is often used during court trials, public issues, in legal acts, codes, handbooks and other sources [9, p. 210].

Recent publications and research: Legal translation as an emerging subbranch within the framework of Translation studies has kindled some significant interest in the scholars working in the legal sphere. Due to the differences in the structure and organization of Ukrainian, European and American legal systems in various nations and countries and the lack of the academic, theoretical and practical sources that would assist in the process of translation, there appears to be great demand and need for research in this sphere. Among the most outstanding scholars working in this field are V.I. Karaban [11], S. Sarcevic [15], A.M. Liashchuk [8], M.B. Verbieniets [5], N.A. Ivanova [6] and N.M. Chernovatyi [11].

The objective of this article is to study the reproduction of legal terminology in English and Ukrainian. This goal is achieved by studying the notion of a legal term suggested by different scholars, legal linguistics as a separate branch of linguistics and analyzing the peculiarities and the means of reproduction of legal terminology into the target language.

Law plays a vital role in reinforcing communication between nations and people and is expressed mainly through legal language. Legal language, as well as other technical languages, fundamentally differs from the language of common use. In order to designate the concept of legal style of presentation, there exists a separate term legalese, which refers to the lexicon peculiar only to legal texts. Legalese is an English term that is commonly used as a synonym to the concept of legal style of presentation. In other words, it is a special legal language, with a special manner of constructing phrases and sentences, for those, who are not well aware of the intricacies of the legal English language, Legalese is most often used in compiling legal acts and judicial decisions, however, sometimes this formalism can be found in the everyday communication of lawyers [7, p. 190]. 
Legal language in its turn is often viewed through the prism of the legal linguistics, the aim of which is to define the main directions to be studied and researched in legal field, namely the history of the legal linguistics, legal lexicography, forensic linguistics, legal stylistics, legal textology, contrastive legal linguistics and legal terminology.

As mentioned previously, the term legal linguistics - is an interdisciplinary field covering the relation between the language and law, linguistics means and categories, linguo-stylistic resources in the sphere of legal communication. The subject of this subdiscipline is the language itself functioning in the spheres of lawmaking and jurisdiction, jurisprudence and education. The key features of legal linguistics both in Ukrainian and English are accuracy, formal style, logical sequence and the high level of standardization [13, p. 101-102].

As it was previously mentioned, law in the scope of legal linguistics is expressed by legal terminology, the smallest unit of which is the notion of a legal term. A number of scholars tried to define the notion of a legal term. According to P. Rabinovich a legal term is a word or word combination expressing the notion taken from the legal sphere of social life and having its definition in the legal literature (legal (restricted) dictionaries, encyclopedias, directories, theses, legal acts) [13, p. 100].

E. Skorokhod'ko apprehends the legal term as a word or a set expression, expressing a special scientific, technical or related to other spheres of human activity concept and having the definition which depicts only those features of the term which are relevant to its field of studies (professional field) [13, p. 101].

One of the core problems in legal terminology is solving the problem of reproduction of legal terms. Translating legal terms needs accurate and correct reproduction and is one of the most difficult among all translation work. Translators should not only possess general knowledge of legal terminology they should also be well aware of requirements.

$N$. Ivanova penetrated into the problem of reproduction of the legal terminology. The main factors of translation are formed taking into account the key features of the language culture, type and the mechanism of the social coding of both the source and target languages. Such an approach helps reveal and form a new standing point for solving the translation-related problems.

$\mathrm{N}$. Ivanova defines two stages in the process of rendering legal terminology:

- Defining the meaning of the term within the context;

- Reproduction of its meaning by the means of a target language.

The main method of translating legal terms is the reproductions by means of lexical equivalent. In other words, by using lexical correspondence, which absolutely coincides with the meaning of the word. Such terms serve as pillars in the text, assisting in revealing the meaning of other words, thus constructing the understanding of the character of the text.

One more aspect, which plays a pivotal role in translating legal terms especiallythe ones expressed in the formofaword-combination, is the analytical stage. This element involves the analysis of all the components of the complex term and their semantic relations between each other and the whole word combination as well. The character of these interrelations defines the order and the content of the term to be rendered. This stage is called synthetic, with its aim being the construction of elements in accordance with their semantic relations and afterwards getting the final version of the translation.

Basing upon the mentioned classifications of legal terms provided by various scholars N. Ivanova worked out a framework of techniques of reproduction of legal terminology:

- Translation by means of lexical equivalent, i.e. using permanent lexical equivalents that exactly match the meaning of the word. In most cases it refers to the borrowed terms of Latin or Greek origin existing in almost every legal system: civil - цивільний, administrative - адміністративний, jurisdiction - юрисдикиія, convention - конвенція;

- Descriptive paraphrase - reproduction providing a widespread common description of what the given notion defines. This technique is applied in case of absence of an adequate correspondence as well as when explanation of the meaning is required; account - несплачена боргова вимога, official accusation - офімійне звинувачення у скоєнні злочину, relevant evidence - докази, що мають стосунок до справи, яка розглядасться;

- Calquing(loan translation)-reproduction of combinatorial structure of a term expressed by a word or a word combination when components of the word (morphemes) or phrase (lexemes) are translated by the corresponding language elements: according to law - відповідно закону, оpening statements - попередні заяви, send to jail - доправти до в'язниці, social security - соиіальний захист, judgement - винесення рішення;

- Transliteration - formal reproduction of original lexical units using the alphabet of the target language: verdict - вердикт;

- Transcription - formal reproduction of original lexical units using the phonemes of the language of translation: Special System Industry - Спешіал Систем Iндастрі;

- The method of practical transcribing - reproduction by using the technique of transcribing but adapting the term to the rules of a target language: criminal - кримінальний, Commercial Code Комерчійний Код;

- Translation bv analogues is used when the term has several dictionary correspondences or the translator adapts the translation to the target text using the term from TL word-stock. In such cases, the translator needs to select an analogue that most accurately conveys the meaning of the term depending on the context: рroceduге - прочедура, порядок, прочес; law - закон, право, законодавство [6, р. 128-129].

Another challenge that arises in the process of rendering legal terms is the problem of polysemy, namely when the dictionary provides more than one equivalent in the target language and the translator has to refer to the context and extralinguistic information to adequately reproduce the meaning of the given term: abolition - усунення, скасування, припинення карного переслідування, ліквідаиія; јиstice - правосуддя, юстичія, суд, законність; charge - заставне право, зобов'язання, розпорядження, вимога [2].

One of the terms that may be of interest to the students and scholars working within the realm of legal translation will be the translation of the term the Bar Bri. [18]. Before analyzing the translated phrase it should be mentioned that in order to practice law the prospective lawyer has to be admitted to the Bar, which entails passing the state Bar exam. This Bar exam can be compared to the Ukrainian expression - екзамен на право займатись адвокатською діяльністю. Bar Bri is the company headquartered in Dallas, Texas the primary product of which is offering a bar 
review course. Because of the general difficulty of the state bar exams, a majority of law school graduates chose to take some form of preparation.

To be thoroughly prepared for the exam lawyers apply for these courses or consult a Bar Bri Handbook - the review of fundamentals in seven major areas covered, namely - torts, contracts, real property evidence, criminal law, civil procedure and constitutional law [17].

When passing the test of such a kind in our culture there is no single directory, an introductory handbook to refer to or a course to apply during the preparatory work for the exam. Moreover, that special term Bar, which is rendered as колегія адвокатів has been often used in the target language without any translation and thus is currently entering the word-stock of Ukrainian special legal terminology as a borrowed term. This is the reason why the translated opted for transcribing as a method of rendering this sample. Still, it has to be mentioned that this way of translation may have caused some misunderstanding by viewers not well aware of such peculiarities in the legal sphere.

Another term to be analyzed is the question whether the title Suits [16] refers to lawsuits or the men wear. The original title of the film was A Legal Mind, which was later renamed into Lawsuits, but shortened to just Suits with the purpose of creating an ambiguous catching title taking into account that the main characters are working for a prestigious law company where being formally dressed is a must. Into Ukrainian, this title was rendered in two ways Форс-мажори and Костюми. [16] The former was copied from the Russian translation and the latter calqued from the original title. In both ways, the title was misinterpreted as the translator did not penetrate into the initial conception of meaning disregarding the deep structure and focused on the surface one.

As far as the version Костюми is concerned, the title was reproduced by using loan translation. When dealing with the second variant of reproduction Форс-мажсори, as it was previously mentioned the translation was calqued from Russian. When working on the best variant the translator failed to reproduce the correct legal meaning but managed to preserve the one in the deep structure. The word мажор [1] according to the dictionary has three meanings, the first one defining the detective series, the second meaning cheerful and vivacious and the last but not least being slang the rich people, in particular, their children, accustomed to an easy and carefree life. The reproduction was mostly focused on the third meaning as the series was set in New York, namely a widely-known company in Manhattan, for the employees of which it is a must to be a graduate of Harvard University. It is a widespread fact the only affluent people may afford to educate their children in this kind of educational establishment.

The word форс-мажор [1] also means something urgent that needs immediate attention, but this definition has nothing to do with legal terminology. Last but not least will be the meaning форс-мажор as a legal term, which in the tort law denotes a serious of circumstances (an earthquake, flood or storm), which could prevent an individual from performing their duty. This very term has no bearing with the plot of the series and just belongs to legal terminology. That is why the translator arrived at the decision to preserve the ear-catching title with its connotations of welfare and making it related to the legal sphere though not connected to the gist of the film using analogue as the method of translation.

The first version Костюми was just the copy of the original, but the translator was not aware of the fact that it was a shortened form of lawsuits, so the reproduction lost its sense. As far as the second version Форс-мажсори is concerned the author tried to reproduce the sense of richness in the deep structure but applied a legal term that can hardly have any relation to the topic of the series.

Conclusions. Law establishes a very specific environment for the transmission of information. The analysis has shown that there exist a number of terms peculiar to the specific nations and cultures causing the discrepancy in meanings and absence of the direct equivalents in the compared languages, which is one of the core problems in reproducing legal terminology. That is the reason why the translator should look for an appropriate equivalent in the target language applying loan translation, transcription and transliteration as the most frequently used methods of reproduction. When working on the translation of the terminological expression one must take into account that the language of law needs precise and accurate reproduction as even the smallest deviation may cause an absolute disruption of its meaning.

\section{References:}

1. Академічний тлумачний словник української мови : в 11 тт. URL: http://sum.in.ua (дата звернення: 29.12. 2019).

2. Андріанов С.М. та ін. Англо-український юридичний словник : близько 75000 термінів / за ред. Л.І. Шевченко. Арій, 2007. 552 с.

3. Андрієвська Е.М. Щодо проблеми адекватності автоматичного перекладу юридичних текстів. Мовні і концептуальні картини світу. 2013. Вип. 2 (44). С. 41-48.

4. Артикуца Н.В. Основи вчення про юридичний термін і юридичну термінологію. Українська термінологія і сучасність. 2005, КНЕУ. Вип. 6. С. 84-89.

5. Вербенєц М.Б. Юридична термінологія української мови: історія становлення і функціонування : автореф. дис. ... канд. філол. наук : 10.02.01 ; Ін-т філології Київського нац. ун-ту Тараса Шевченка. Київ, 2004. 15 с.

6. Іванова Н.А. Англомовна юридична термінологія та засоби іï адекватної передачі українською мовою. Наукові записки. Серія : «Філологічні науки». 2012. Вип. 104. С. 126-129.

7. Когосонова О.В. Юридический дискурс: лингвопрагматика имени собственного. Знание. Понимание. Умение. 2008. Вип. 2. С. $188-192$.

8. Лящук А.М. Семантична структура юридичних термінів української та англійської мов : автореф. дис. ... канд. філол. наук : 10.02.07; Київський нац. лінгвістичний ун-т. Київ, 2007. 22. с

9. Нікіфорова С.М. Особливості юридичної термінології в англійській мові. Збірник наукових праць Харківського національного педагогічного університету імені Г. Сковороди. «Право». 2012. Вип. 19. С. 173-179.

10. Савчук Г.П. The difficulties in translating legal terminology (on the basis of legal documentation). Південний архів (філологічні науки) : зб. наук. пр. Херсон : ХДУ. 2018. Вип. 74. С. 209-212.

11. Черноватий Л.М., Карабан В.І., Іванко Ю.П. Переклад англомовної юридичної літератури : навч. посібник для студентів вищих навчальних закладів освіти. Вінниця : Поділля, 2002. 448 с.

12. Юридична енциклопедія : в 6 тт. / ред. рада.: Ю.С. Шемшученко (гол.) та ін.; Українська енциклопедія ім. М.П. Бажана. Київ, 2004. T. $6.768 \mathrm{c}$.

13. Яцишин Н.П. Юридична термінологія як спеціалізована система правових понять. Термінологічний вісник: зб. наук. пр. 2013. C. 99-103.

14. Longman Dictionary of Contemporary English. 4th ed. Harlow, England : Longman, 2005. 2082 p.

15. Sarcevic S. Legal Translation and Translation Theory: A Receiveroriented Approach. Legal translation: History, Theory, Practice. University of Geneva. 2000. P. 329-347. 
16. Серіал «Форс-мажори / Костюми». Сезон 1-3. URL: https://uafilm. tv/837-fors-mazhory.html (дата звернення: 2. 12. 2019).

17. BarBri. Wikipedia: The Free Encyclopedia: URL: https://en. wikipedia. org/wiki/Barbri.

18. Legal drama series "Suits". Season 1-3. URL. https://www.netflix. com/browse?jbv=70195800\&jbp=0\&jbr=1 (дата звернення: 02.12.2019).

Цимбрило В. І. Ключові проблеми відтворення юридичної лексики в українському перекладі серіалу "Suits"

Анотація. У статті окреслено поняття юридичної термінології в межах перекладознавства як окремої дисципліни та методи іiі відтворення 3 англійської на українську.

Право - каталізатор комунікації між країнами та націями світу, а юридичний переклад - нова царина перекладознавства, яка внаслідок культурної різноманітності та процесу глобалізації набуває все більшого значення на міжнародній арені. 3 огляду на те, що це відносно нова галузь перекладознавства, яка ще не вичерпала свого потенціалу, багато перекладознавців та юристів, серед яких - В.І. Карабан, С. Сарцевич, А.М. Лящук, М.В. Веребенєц. Н.А. Іванова та Н.М. Черноватий, активно досліджують цю сферу. Юридична мова, як і інші технічні мови, відрізняється від повсякденної та часто розглядається як складник юридичної лінгвістики. Метою останньої $€$ вивчення юридичного аспекту мови, взаємодії мови та права, а також дослідження питання юридичної лексикографії, стилістики, текстології, контрастивної юридичної лінгвістики та юридичної термінології.
Право як піддисципліна юридичної лінгвістики виражається за допомогою юридичної термінології, найменшою одиницею якої $\epsilon$ поняття юридичного терміна.

Однією 3 основних проблем правової термінології $\epsilon$ відтворення юридичних термінів. Переклад термінів вимагає точного перенесення значення 3 мінімальними його відхиленнями в цільовій мові. Перекладачу не досить володіти термінологією, вони також повинні бути компетентними у структурі та організації правової системи тієї чи іншої держави чи культури. В процесі відтворення перекладач повинен узяти до уваги такі фактори: мовну культуру, тип і механізм кодування в мові оригіналу та перекладу.

Наступною проблемою перекладу юридичної термінології $\epsilon$ їхня полісемантична природа, тобто коли словник пропонує більше, ніж один відповідник цьому терміну. В такому випадку задля адекватного та правильного перекладу до уваги беруться також контекст та екстралінгвістична інформація.

С декілька способів перекладу юридичних термінів залежно від їхнього походження, значення, наявності такого ж поняття в правовій системі цільової аудиторії та відповідного еквівалента в перекладі. Відсутність відповідника терміну створює труднощі в процесі перекладу, в цьому випадку перекладач намагається знайти відповідник цьому терміну або ж запропонувати власний варіант та ознайомити аудиторію з новою версією перекладу.

Ключові слова: право, юридична лінгвістика, юридична термінологія, методи перекладу, відсутність відповідника, полісемантичність. 